\title{
Antioxidant stone water (human/friendly environment) thermal (thermogravimetric-TGA) combustion properties in biohazard (insect/fungus) wood
}

\author{
Hüseyin Tan ${ }^{1 *}$ (D), Hatice Ulusoy² and Hüseyin Peker ${ }^{3}$ \\ ${ }^{1}$ Department of Furniture and Decoration Technology, Recep Tayyip Erdo an University, Rize, Turkey \\ ${ }^{2}$ Department of Forest, Muğla Sıtkı Koçman University, Mu la, Turkey \\ ${ }^{3}$ Department of Forestry, Artvin Çoruh University, Artvin, Turkey \\ *gakkomtan@hotmail.com
}

\begin{abstract}
In this study, four different wood species walnut (Juglans regia L.), chestnut (Castanea sativa Mill.), Poplar (Populus nigra), scotch pine (Pinus sylvestris L.) were chosen and test samples were prepared according to TS 2470 principles. Especially the pine wood by taking the structure (with fungus, fungus/insect, insect), flawless wood structure is compared with the flawed wood structure. The impregnation process was carried out according to ASTM D $1413-76$ principles. Effects of the chemical characteristics of the determined Stone Water (Firetex) on the thermal decomposition properties of wood (burning degrees, degradation temperature points and residue amount) were determined with TGA (thermogravimetric analysis). According to the results of the experiment; the highest retention value was found in poplar $(23.56 \%)$ and the lowest retention $(12.79 \%)$ in chestnut was determined. Amount of residue; $60.84 \%$ of the highest on scotch pine wood with fungus and $56.70 \%$ of the lowest value was determined on poplar wood. Thermal deterioration was determined between $226.41-405.04{ }^{\circ} \mathrm{C}$ on wood .
\end{abstract}

Keywords: stone water, walnut, chestnut, poplar, scots pine, thermal properties.

How to cite: Tan, H., Ulusoy, H., \& Peker, H. (2020). Antioxidant stone water (human/friendly environment) thermal (thermogravimetric-tga) combustion properties in biohazard (insect/fungus) wood. Polímeros: Ciência e Tecnologia, 30(2), e2020014. https://doi.org/10.1590/0104-1428.00720

\section{Introduction}

Nowadays, due to the rapidly increasing world population and the increasing needs of humankind due to developing technology and living standards, natural resources are decreasing as a result of unconscious consumption. This forces producers to engage in studies on how they can use natural resources more efficiently and in a variety of ways. Wood material, which has a wide range of usage, is a natural and renewable raw material that can be applied to all areas. Due to its light weight compared to concrete, iron, aluminum, PVC and various other construction materials, being easy to be processed, having continuous production, having superior physical and mechanical properties in various places for use; the wood has a wide range of unique uses in construction techniques, many industries such as paper and cellulose, sheet, furniture. At the same time, due to the sensitivity towards fire safety, it is emphasized that fire resistance of wood material is provided in the most effective way. In addition to the known combustion properties of wood material, it is of great importance to determine the effect of impregnation process on combustion resistance. Wood is a flammable material since it is an organic based material containing carbon and hydrogen. The temperature must be

increased to $275^{\circ} \mathrm{C}$ to able to burn for wood. However, it can ignite in any kind of flame source even at much lower temperatures. In order to burning of wood, there must be one of the three; oxygen, a source of burning heat and a flammable substance. If this trio is not available, there will be no ignition ${ }^{[1]}$.

One of the negative properties of wood material is that it is an organic material. Therefore, burning is one of the important negative properties in case of proper conditions. Apart from the flammability of wood material, other negative properties cause only material losses, while life-threatening of wood material also occurs. The flames and gases created by the burning of wood material threaten human life and may cause death ${ }^{[2]}$. One of the most negative properties of wood material is that it is flammable. In order to eliminate this negative feature of wood material, many chemicals are applied to prevent or delay fire. Combustion properties of scotch pine wood treated with a mixture of boric acid and borax, various natural sepi materials as an anti-combustion or retarding agent in wood material were investigated. It was found that natural sepi substances had a negative effect on the examined combustion parameters, the combustion 
properties of scotch pine treated with natural sepi substances were similar to control or worse than the control and it has been determined that some of the burning characteristics of the scotch pine wood treated with natural sepi substances have improved significantly statistically ${ }^{[3]}$.

The wood begins to break its chemical bond at temperatures above $100{ }^{\circ} \mathrm{C}$. Regular weight loss in wood occurs between 100 and $200{ }^{\circ} \mathrm{C}$ and $\mathrm{CO}_{2}$, acetic acid, water vapor and small amounts of formic acid are released in this temperature range. Lignin decomposes at $160^{\circ} \mathrm{C}$, cellulose disintegrates above $200{ }^{\circ} \mathrm{C}$, tar and flammable volatiles can spread into the environment. Exothermic reactions start at $200-260^{\circ} \mathrm{C}$, combustion also occurs in parts where hydrocarbons with a low boiling point are exposed. Heat release occurs at $275-280^{\circ} \mathrm{C}$, while ethanoic acid, methanol and homologs of these substances increase in gas and liquid products. The wood can also continue to burn after the heat source has been removed. Depending on the characteristics, burning in wood that ignites in the range of $300-400{ }^{\circ} \mathrm{C}$ continues to approximately $450{ }^{\circ} \mathrm{C}$. When the temperature rises above $450{ }^{\circ} \mathrm{C}$, while coal remains, decomposition, carbon dioxide, carbon monoxide and oxidation water accelerate and goes to even further stages ${ }^{[4,5]}$.

In a study; In order to protect wood against biotic and abiotic pests, the effect of various impregnating agents on the firing properties of firewood was investigated. As a result, it was found that aqueous solutions of boron compounds showed significant anti-fire effect ${ }^{[6]}$. In the study, the effects of various impregnation agents on the burning properties of alder wood were investigated and as a result of the study, it was investigated that boron compounds significantly reduced combustion of alder wood ${ }^{[7]}$. In addition to the effect of boron compounds against fungi and insects, it has many activities such as preventing the transfer of heat and preventing the material from meeting with oxygen as a fire inhibitor ${ }^{[8,9]}$. The rate of combustion and the degree of combustion are important for the effect of fire on wood material. Since no combustion occurs in the absence of oxygen, carbonization begins after a slow combustion occurs in the wide cross-section material ${ }^{[7]}$. This carbonization acts as an insulating material on thick wood surfaces and reduces the degree of fire damage on the inner parts of wood material ${ }^{[10,11]}$. Stone water (firetex) is a water based fireproof containing limestone mineral formula; It has been reported that it has no adverse effects on humans and animals and that stone water can be applied to increase the burning resistance of wood materials ${ }^{[12-14]}$.

The wood material consists of a mixture of complex organic polymers. Changes in wood material components occur due to temperature. Thermogravimetric Analysis (TGA) method is implemeted to determine the thermal stability of wood material. By determining the mass losses that occur while heating the material whose thermal properties will be determined, the temperature value at which the fracture occurs from the graph of temperature-mass loss is provided as the decomposition temperature. The 1st degree derivative of weight loss (DTGA/Differential Thermal Analysis) is utilized to determine decomposition temperatures. The wood material consists of a mixture of complex organic polymers. Changes in wood material components occur with temperature ${ }^{[15]}$.

\section{Materials and Methods}

\subsection{Material (Wood and Chemical)}

In this study, scotch wood (with fungus, insect, insect + fungus), poplar, chestnut and walnut material was preferred, stone water (firetex) was used at a concentration of $100 \%$ in the impregnation process.

\subsection{Preparation of test samples}

Boric Wood sample of scotch pine (coniferous wood species) species with fungus, insect-fungus, and (leafed wood species) walnut, chestnut and poplar were taken as wood chips to represent the whole mass of the sample, milled in laboratory Willey mill and sieved in 40 and 60 mesh sieves. The obtained samples were subjected to impregnation process.

\subsection{Impregnation method}

For the impregnation procedure, distilled water was used to prepare aqueous solutions of the wood preservatives which have concentration of $3 \%$. Approximately $100 \mathrm{~g}$ of the wood flour was immersed in the solutions for $2 \mathrm{~h}$ at $60^{\circ} \mathrm{C}$. Until obtaining the unchangeable weight, The treated wood specimens were exposed to drying at $60{ }^{\circ} \mathrm{C}$. They were followed for the impregnation procedure of wood flour and wood specimens ${ }^{[16,17]}$. Then, for two weeks, wood specimens were moistured at $65 \%$ relative humidity and at $20{ }^{\circ} \mathrm{C}$.

\subsection{Thermal analysis}

In conditions with heating rate of $10^{\circ} \mathrm{C} / \mathrm{min}$ and a purge rate of $50 \mathrm{~mL} / \mathrm{min}$ (Argon) by using a LABSYS TG-DTA analyzer between room temperature to $600^{\circ} \mathrm{C}$, thermogravimetric analysis (TGA) and Differential thermal analysis (DTA) were implemented under nitrogen atmosphere. $10 \mathrm{mg}$ of the sample was analyzed and weight loss of the sample was noted continuously for each individual experiment. By using TG curve as a function of time, derivative TG (DTG) curves were applied.

\section{Results and Discussions}

\subsection{Experimental results}

The solution properties are given in (Table 1).

The solution concentration was used as $100 \%$ and the $\mathrm{pH} /$ density values were determined before and after impregnation. It has been reported in the literature that acidic structure may cause adversities in anatomical/technological structure of wood.

\section{$3.2 \%$ Retention}

$\%$ Retention values are given in (Table 2) and related graph in (Figure 1)

According to BVA and Duncan test results; When \% retention was evaluated, wood structure with low specific gravity had a positive effect on $\%$ retention, whereas wood structure with high specific gravity gave low results. It is evaluated that the highest retention value was $23.56 \%$ in poplar and the lowest retention was $12.79 \%$ in chestnut. Differences in retention rates may arise from the type of wood, the anatomical structures of the trees, and therefore their physical properties, the impregnation 
process and the solution. It is investigated that many factors related to anatomical structure such as heartwood, sapwood, spring wood, summer wood, density, heart beam, tracheid, resin in wood affect permeability ${ }^{[18]}$.

\subsection{Thermogravimetric (TGA) Analysis}

Samples impregnated using four different tree species were compared with control (non-impregnated) samples. TGA analysis was applied for thermal strength of the samples and DTG curves were generated. The results of thermogravimetric (TGA) analysis of scotch pine wood are given below. Figure 2 shows the TGA (2-a) and DTG (2-b) curves of firetex-treated scotch pine with insect-fungus and control sample. While the turning point temperature of the control sample was $381.14{ }^{\circ} \mathrm{C}$, the decomposition temperature of the firetex applied samples decreased to $361.24^{\circ} \mathrm{C}$. The acceleration of degradation is due to the fact that bonds such as P-O-C (Phosphorus-Carbon) in fire retardants are much less stable than $\mathrm{C}-\mathrm{C}$ bonds in the control

Table 1. The solution properties.

\begin{tabular}{|c|c|c|c|c|c|c|c|}
\hline \multirow{2}{*}{ Solution (\%) } & \multirow{2}{*}{$\begin{array}{c}\text { Impregnation } \\
\text { material }\end{array}$} & \multirow{2}{*}{$\begin{array}{l}\text { Solvent } \\
\text { material }\end{array}$} & \multirow{2}{*}{$\begin{array}{l}\text { Temperature } \\
\left({ }^{0} \mathrm{C}\right)\end{array}$} & \multicolumn{2}{|c|}{ pH } & \multicolumn{2}{|c|}{ Density } \\
\hline & & & & BI & AI & BI & AI \\
\hline $100 \%$ & Stone Water & Destile water & $22^{\circ} \mathrm{C}$ & 1.65 & 1.65 & 1.215 & 1.215 \\
\hline
\end{tabular}

BI: Before impregnation, AI: After impregnation.

Table 2. \% Retention values and duncan test results.

\begin{tabular}{ccccc}
\hline S.No & $\begin{array}{c}\text { Wood Type } \\
\text { (Control) }\end{array}$ & $\begin{array}{c}\text { Treatment } \\
\text { Wood }\end{array}$ & \% Retention & HG \\
\hline $\mathbf{1}$ & Yellow pine (With fungi+insect) & Yellow Pine & 18,17 & \\
$\mathbf{2}$ & Yellow pine (With insect) & (Firetex) & 14,35 & \\
$\mathbf{3}$ & Yellow pine (With fungus) & Walnut (Firetex) & 12,79 & \\
$\mathbf{4}$ & Walnut & Chestnut (Firetex) & D \\
$\mathbf{5}$ & Chestnut & Poplar (Firetex) & 23,56 \\
$\mathbf{6}$ & Poplar & & A \\
\hline
\end{tabular}

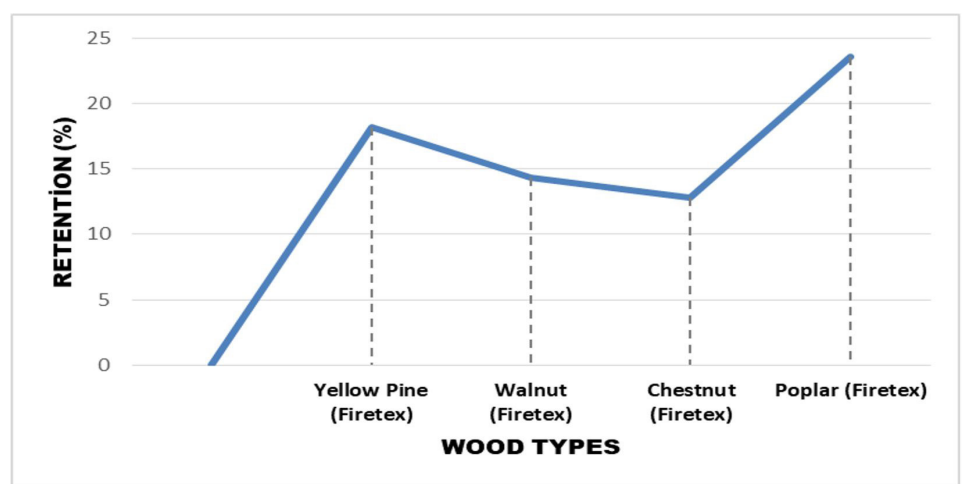

Figure 1. \% Retention change.



$\mathbf{a}$

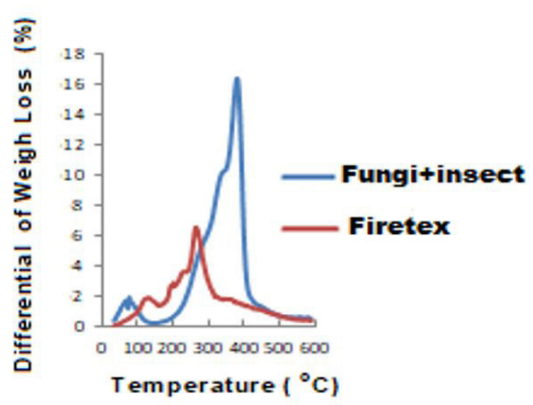

Figure 2. TGA (a), and DTG (b) curves in Scotch pine (with fungus+insect). 
sample and are usually caused by degradation of $180{ }^{\circ} \mathrm{C}$ ${ }^{[16]}$. This early decomposition prevents the formation of flammable gases and also supports formation of carbonized coal $^{[19]}$. While the amount of residues from combustion result of the control sample was $19.10 \%$, the amount of residues from carbonization result in the sample containing firetex increased to $56.73 \%$.

Figure 2 shows the TGA (Figure 3a) and DTG (Figure 3b) curves of scotch pine wood with insects. While the turning point temperature of the control sample was $370.62{ }^{\circ} \mathrm{C}$, the decomposition temperature of the firetex applied samples decreased to $262.26^{\circ} \mathrm{C}$. The acceleration of degradation is due to the fact that bonds such as $\mathrm{P}-\mathrm{O}-\mathrm{C}$ (Phosphorus-Carbon) in fire retardants are much less stable than $\mathrm{C}-\mathrm{C}$ bonds in the control sample and are usually caused by degradation of $180^{\circ} \mathrm{C}^{[16]}$. This early decomposition prevents the formation of flammable gases and also supports the formation of carbonized coal ${ }^{[19]}$. While the amount of residues from combustion result of the control sample was $20.39 \%$, the amount of residue from carbonization result in the sample containing firetex increased to $53.19 \%$.

Figure 4 shows the TGA (Figure 4a) and DTG (Figure 4b) curves of scotch pine wood with fungus. While the turning point temperature of the control sample was $373.71{ }^{\circ} \mathrm{C}$, the decomposition temperature of the firetex treated samples decreased to $281.20{ }^{\circ} \mathrm{C}$. The reason for the accelerated degradation may result from the chemical structure of the wood. While the amount of residues from combustion result of the control sample was $18.59 \%$, the amount of residue of from firetex containing sample from carbonization increased to $60.84 \%$. The degradation of the wood components was very rapid, weight loss after the decomposition temperature

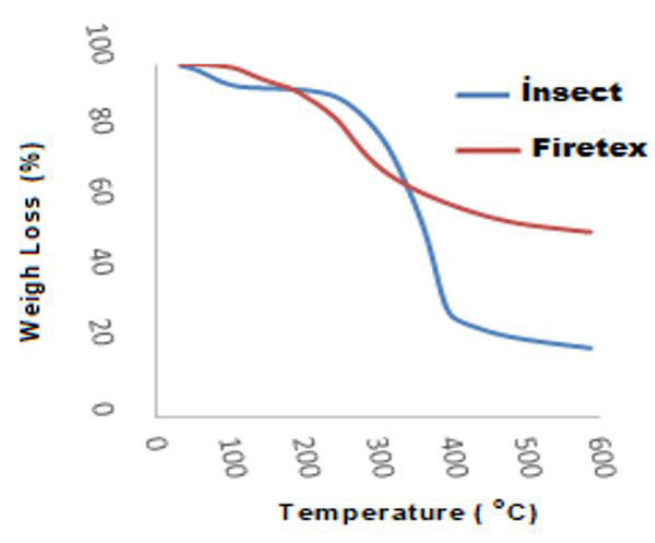

a

Figure 3. TGA (a), and DTGA (b) curves in Scotch pine with insect.

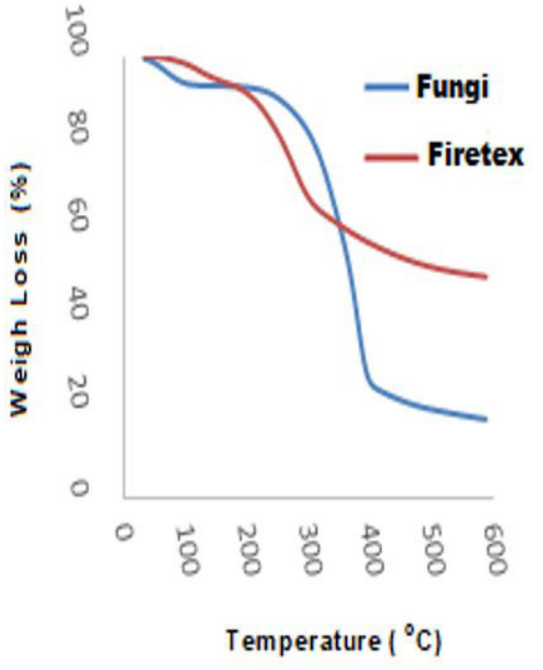

a

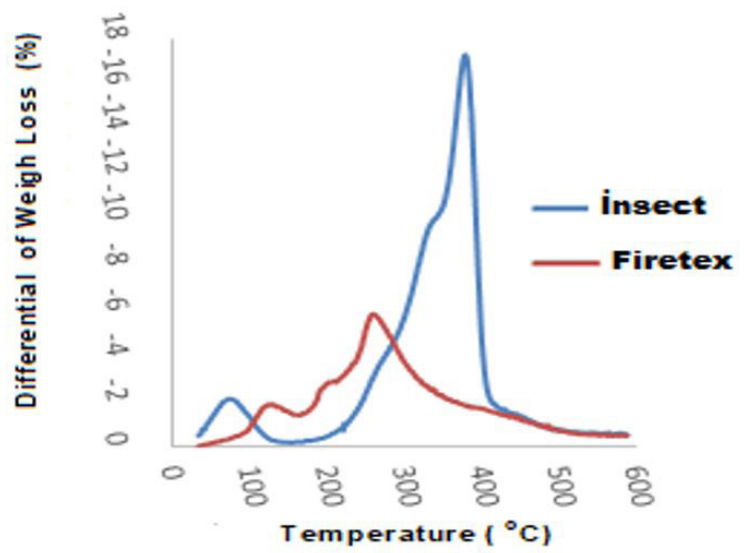

b

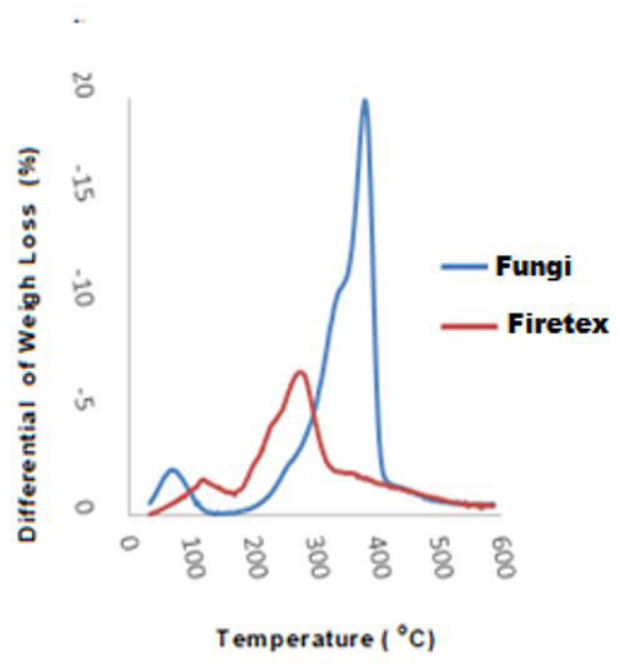

Figure 4. TGA (a), and DTG (b) curves in scotch pine wood with fungi. 
was less. The degradation of wood components in defective scotch pine with fungus was very rapid and the weight loss was lower after the decomposition temperature. The rapid degradation may arise from the destruction of the fungus inside the wood.

Figure 5 shows the TG (Figure 5a) and DTG (Figure 5b) curves of walnut wood. While the turning point temperature of the control sample was $370.14{ }^{\circ} \mathrm{C}$, the decomposition temperature of the firetex treated samples decreased to $226.41{ }^{\circ} \mathrm{C}$. The reason for the accelerated degradation may result from the chemical structure of the wood. While the amount of residues from combustion result of the control sample was $21.00 \%$, the amount of residue from carbonization result was $59.00 \%$ in the sample containing firetex. The degradation of the wood components was very rapid, weight loss was less after the decomposition temperature. In these two stages, the stone water in the lumens forming the cavities of the wood cells was removed from the environment depending on the temperature. It is found that thermal decomposition of wood flour and wood components was between $300-500{ }^{\circ} \mathrm{C}[15]$.

Figure 6 shows the TG (Figure 6-a) and DTG (Figure 6-b) curves of chestnut wood. Chestnut wood is in the category of leafed trees such as walnut wood. Therefore, TG and DTG analysis showed similar results like walnut samples. While the turning point temperature of the control sample was $405.04{ }^{\circ} \mathrm{C}$, the decomposition temperature of the firetex treated samples decreased to $265.96^{\circ} \mathrm{C}$. The reason for the accelerated degradation result from the chemical structure of the wood. While the amount of residues from combustion result of the control sample was $26.37 \%$, the amount of residue increased to $58.03 \%$ from carbonization result in the sample containing firetex. The degradation of the wood components was very rapid, weight loss after the decomposition temperature was less. In these two stages, the stone water in the lumens forming the cavities of the



a

Figure 5. TGA (a), and DTG (b) curves in Walnut wood.



$\mathbf{a}$



$\mathrm{b}$

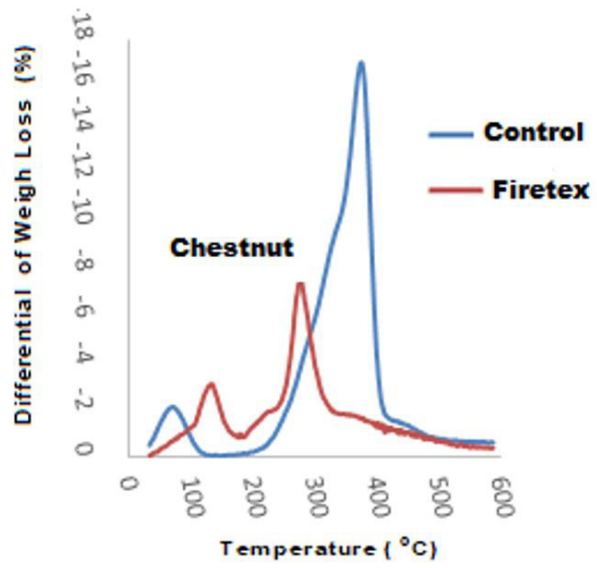

b

Figure 6. TGA (a), and DTG (b) curves in Chestnut wood. 
wood cells was removed from the environment depending on the temperature. This may arise from anatomical structure. Cellulose depolymerization is very quick and anhydro-sugars at above $300{ }^{\circ} \mathrm{C}$, haphazardly connected oligosaccharides and levoglucosan are shaped ${ }^{[20]}$. Collard and Blin clairified that char has an aromatic polycyclic structure. Higher crosslinking and thermal stability of the residue arise from intra- and intermolecular rearrangements lead to ${ }^{[2]]}$.

Figure 7 shows the TG (Figure 7-a) and DTG (Figure 7-b) curves of poplar wood. Poplar wood is in the category of leafy trees such as walnut and chestnut wood. Therefore, TG and DTG analyses showed similar behaviors to walnut and chestnut samples. While the turning point temperature of the control sample was $382.580{ }^{\circ} \mathrm{C}$, the decomposition temperature of the firetex treated samples decreased to $247.04{ }^{\circ} \mathrm{C}$. The reason of accelerated degradation may arise from the chemical structure of the wood. While the amount of residues from combustion result of the control sample was $17.03 \%$, the amount of residue from carbonization result in the sample containing firetex increased to $56.70 \%$. The degradation of the wood components was very rapid, weight loss after the decomposition temperature was less. In these two stages, the stone water in the lumens forming the cavities of the wood cells was removed from the environment depending on the temperature. This may arise from anatomical structure. Normally, wood has a bigger shoulder area because of debasement of cellulose ${ }^{[22,23]}$. Then, because of cellulose macromolecules, the sharp decline in weight can be seen at $351^{\circ} \mathrm{C}$. Degradation of lignin begins and the residue includes primarily of charcoal from lignin decomposition at temperatures above $351{ }^{\circ} \mathrm{C}^{[24]}$.

In this study, in which TG / DTG analyzes of pine, walnut, chestnut and poplar wood impregnated with stone water (Firetex) were carried out, it was determined that the effects of stone water against combustion were thermally demonstrated. When the variations were compared with the control samples, increases in the remaining mass ratios ranging from $53.19 \%$ (scotch pine with insect) to $60.84 \%$ (scotch pine with fungus) were observed. In the retention rate changes, different rates were determined depending on the physical and anatomical structure of the wood. In a study, according to the results of the combustion test carried out on scotch pine wood treated impregnation with stone water using immersion process, significant differences were found in the remaining mass and released $\mathrm{CO}$ gas ratios ${ }^{[13]}$.

\section{Conclusions}

Due to their anatomical structure and texture differences, the resistance of wood material against burning is also different. In this study, the thermal properties of wood impregnated with stone water were investigated. In this study, TG/DTG analyzes of defective woods of scotch pine with insect and fungus (impregnated with stone water (Firetex)), and walnut, chestnut and poplar woods; It has been determined that the effects of stone water against combustion are also thermally demonstrated. Wood structure with low specific gravity positively affected $\%$ retention, wood structure with high specific gravity gave low results. When the variations were compared with the control samples in itself, increases in mass losses were observed depending on species. On the other hand, it showed different rates depending on the physical and anatomical structure of the wood. It was observed that stone water affects thermal properties. To clarify this situation, comparisons can be made with the results of thermal analysis by calculating the impregnated stone water at different times $(2,4,6,12$ hours).

TGA results can be applied in the production of wood material such as medium-density fiberboard (MDF), particle board, plywood and wood/plastic composites, to explain some of the behavior of wood material against combustion, to evaluate the performance of fire retardants and to obtain fuel from biomass.

All chemical compounds are effective on the combustion, physical and mechanical properties of wood. The fireproofing

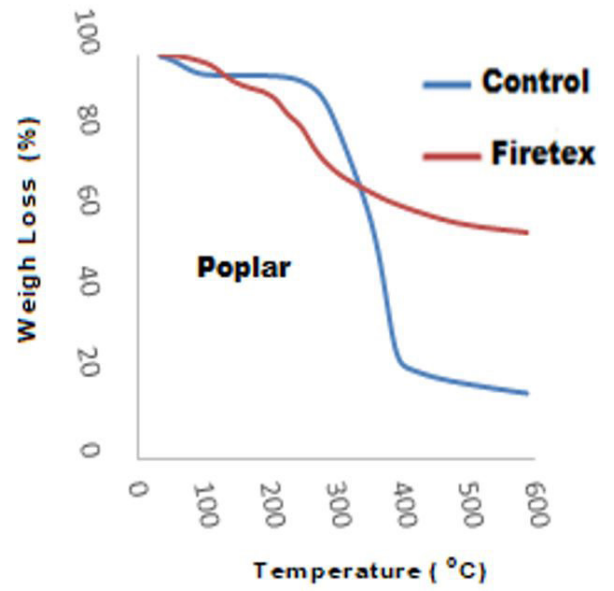

a

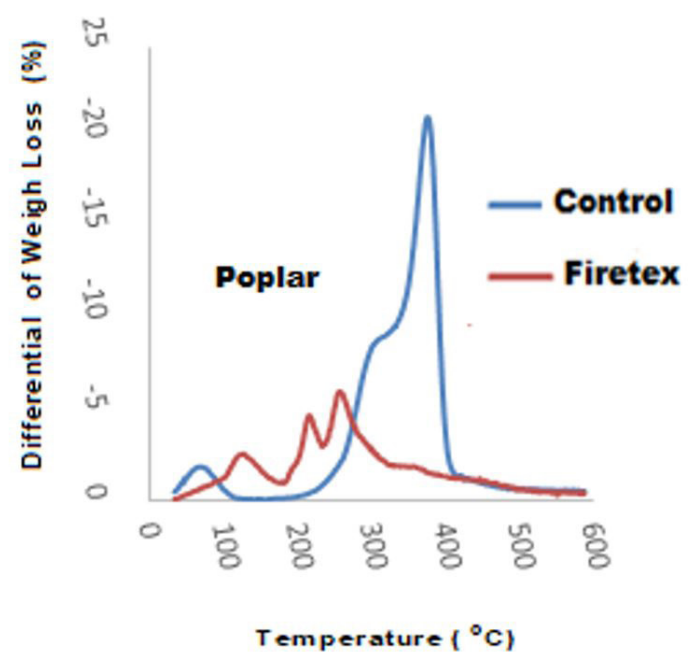

b

Figure 7. TGA (a), and DTG (b) curves in poplar wood. 
ability, color, density, odor, taste and resistance to pressure of wood vary depending on the amount of extractive material. As the amount of extractive material decreases in wood, its ability to burn decreases. The increase in lignin and inorganic material (ash) ratio decreases combustion resistance. For further, studies can be conducted on how these substances affect TGA results.

In Balikesir / Edremit, stone water, whose effects are tested in different areas, is used as a preventive agent against fires and it has been determined that the stone water registered as a strong oks antioxidant 'by Balıkesir Univer Eskişehir Osman Gazi University Faculty of Arts and Sciences Department of Biology. Dr. Adnan Ayhanci, stone water and lung and prostate cancer has reported that the effect of preventing the cells reported.sity has the power to kill germs in 6 tons when it is mixed with 1.5 tons of sewage water ${ }^{[25]}$.

\section{References}

1. Kolman, F., \& Cote, J. R. (1968). Principles of wood science and technology: I Solid Wood. Berlin: Springer-Verlag Berlin Heidelberg. http://dx.doi.org/10.1007/978-3-642-87928-9.

2. Terzi, E. (2008). Combustion properties of wood material impregnated with Ammonium Compounds (Master's dissertation). İstanbul University Institute of Science, Turkey.

3. Baysal, E., Peker, H., Çolak, M., \& Tarımer, İ. (2003). Combustion properties of varnished wood material and the effect of preimpregnation with boron compounds on fire retardant effect. Firat University Journal of Science and Engineering Sciences, 15(4), 645-653.

4. Evan, S. L. (1989). Thermal degredation. In: A. P. Schniewind, Concise encylopedia of wood\&wood based materials (pp. 271-273). New York: Pergamon Press.

5. Russel, L. J., Marney, D. C. O., Humphrey, D. G., Hunt, A. C., Dowling, V. P., \& Cookson, L. J. (2007). Combining fire retardantand preservative systems fortimber products in exposedapplications-state of the art review (Project no: PN04, 10-12). Australia: Forest and Wood Products Research and Development Corporation.

6. Yalınkılıç, M. K., Demirci, Z., \& Baysal, E. (1998). Effects of various impregnating agents on the burning properties of duglas [Pseudotsuga menziesii (Mirb.) Frankco] wood. Pamukkale Ünversity Engineering Science Journal, 4(2), 613-624.

7. Uysal, B. (1998). Burning properties of alder wood of various water-repellent and fire-retardant chemicals. Zonguldak Karaelmas University Technology Journal, 2, 81-89.

8. Çavdar, A. D., Mengeloğlu, F., \& Karakuş, K. (2015). Effect of boric acid and borax on mechanical, fire and thermal properties of wood flour filled high density polyethylene composites. Measurement, 60, 6-12. http://dx.doi.org/10.1016/j. measurement.2014.09.078.

9. Price, D., Anthony, G., \& Carty, P. (2001). Polymer combustion, condensed phase pyrolysis and smoke formation. In A. R. Horrocks, \& D. Price (Eds.), Fire Retardant Materials (pp. 1-30). Cambridge, UK: Woodhead Publishing.

10. Uysal, B. (1997). Effects of various chemicals on the fire resistance of wood materials (Master's dissertation). Turkey: Gazi Ünıversity Institute of Science.

11. White, R. H., \& Dietenberger, M. A. (1999). Fire safety. In Forest Products Laboratory. Wood handbook: wood as an engineering material (pp. 17.1-17.16). Madison, WI: USDA Forest Service.

12. Tomak, E. D., \& Çavdar, A. D. (2013). Limited oxygen index levels of impregnated Scots pine wood. Thermochimica Acta, 573, 181-185. http://dx.doi.org/10.1016/j.tca.2013.09.022.

13. Kesik, H. İ., Aydoğan, H., Çağatay, K., Özkan, O. E., \& Maraz, E. (2015). Fire Properties of Scots Pine Impregnated with Firetex. In International Conference on Environmental Science and Technology (pp. 122-127). Sarajevo: ICOEST.

14. Özcan, C., Kurt, Ş., Esen, R., \& Korkmaz, M. (2016). The determinate combustion properties of fir wood impregnated with fire-retardants. The Online Journal of Science and Technology, 6(3), 77-82.

15. Tutuş, A., Kurt, R., Alma, M. H., \& Meriç, H. (2010). Chemıcal analysis of scotch pine wood and its thermal properties. In III Ulusal Karadeniz Ormancllk Kongresi (pp. 1845-1851). Artvin: Artvin Çoruh Üniversitesi Orman Fakültesi. Retrieved in 2020, June 17. from http://karok3.artvin.edu.tr/V.Cilt/(1845-1851). pdf

16. Jiang, J., Li, J., Hu, J., \& Fan, D. (2010). Effect of nitrogen phosphorus flame retardants on thermal degradation of wood. Construction \& Building Materials, 24(12), 2633-2637. http:// dx.doi.org/10.1016/j.conbuildmat.2010.04.064.

17. Yunchu, H., Peijang, Z., \& Songsheng, Q. (2000). TG-DTA studies on wood treated with flame retardants. Holz als Roh- und Werkstoff, 58(1), 35-38. http://dx.doi.org/10.1007/ s001070050382.

18. Flynn, K. A. (1995). Review of the permeability, fluid flow, and anatomy of spruce (Picea spp.). Wood Fiber Scieence. 27(3), 278-284.

19. Basak, S., Samanta, K. K., Chattopadhyay, S. K., \& Narkar, R. (2015). Thermally stable cellulosic paper made using banana pseudostem sap, a wasted by-product. Cellulose, 22(4), 27672776. http://dx.doi.org/10.1007/s10570-015-0662-7.

20. Shafizadeh, F. (1982). Introduction to pyrolysis of Biomass. Journal of Analytical and Applied Pyrolysis, 3(4), 283-305. http://dx.doi.org/10.1016/0165-2370(82)80017-X.

21. Collard, F.-X., \& Blin, J. (2014). Review on pyrolysis of biomass constituents: mechanisms and composition of the products obtained from the conversion of cellulose, hemicelluloses and lignin. Renewable \& Sustainable Energy Reviews, 38, 594-608. http://dx.doi.org/10.1016/j.rser.2014.06.013.

22. Beall, F. C., \& Eickner, H. W. (1970). Thermal degradation of wood components: a review of the literature. Madison, WI: U.S. Forest Products Laboratory. US Department of Agriculture United States Forest Service.

23. Jeske, H., Schirp, A., \& Cornelius, F. (2012). Development of a Thermogravimetric Analysis (TGA) method for quantitative analysis of wood flour and polypropylene in Wood Plastic Composites (WPC). Thermochimica Acta, 543, 165-171. http:// dx.doi.org/10.1016/j.tca.2012.05.016.

24. Slopiecka, K., Bartocci, P., \& Fantozzi, F. (2012). Thermogravimetric analysis and kinetic study of poplar wood pyrolysis. Applied Energy, 97, 491-497. http://dx.doi. org/10.1016/j.apenergy.2011.12.056.

25. Haberler.com. Ballkesir 'stone water'study against cancer. (2019). Retrieved in 2020, June 17, Retrieved from https:// www.haberler.com/balikesir-kansere-karsi-tas-suyu-calismasi12430326-ha/

Received: Apr. 23, 2020 Accepted: June 17, 2020 